\title{
FAKTOR-FAKTOR YANG MEMPENGARUHI STRUKTUR MODAL PADA PERUSAHAAN MANUFAKTUR YANG TERDAFTAR DI BEI
}

\author{
Achmad Agus Priyono \\ Jurusan Manajemen Fakultas Ekonomi Universitas Islam Malang \\ (UNISMA) \\ Jln.MT. Haryono 193 Dinoyo-Malang 65144 \\ E-mail: aapuim@yahoo.com
}

\begin{abstract}
The aim of this study is to examine the causality relationship between structures of assets, firm size, operating leverage, profitability, liquidity, growth of sales, and capital structure. Testing manufactures listed in Indonesian stock market resulted in the estimation structural equation model which is fit and acceptable. Multiple R-square of 0.259 indicate that the change in capital structure is defined by structure of assets (SA), Growth of sales (GS), operating leverage $(\mathrm{OL})$, firm size (FS), liquidity (LQ) and profitability (PR) of $25.9 \%$; while the remaining $74.1 \%$ is defined by changes of other variables which were not included in the model.
\end{abstract}

Keywords: Struktur modal, ukuran perusahaan, leverage operasi, profitabilitas, likuiditas.

Fungsi keuangan merupakan salah satu fungsi penting dalam aktivitas perusahaan. Salah satu keputusan penting dalam pengelolaan fungsi keuangan yaitu seberapa besar perusahaan mampu memenuhi kebutuhan dana yang digunakan untuk beroperasi ataupun mengembangkan usahanya. Untuk memenuhi kebutuhan dana ini perusahaan dapat memperoleh dana dari dalam perusahaan (internal financing) atau dari luar perusahaan (external financing). Pemenuhan kebutuhan dana perusahaan dari sumber modal sendiri berasal dari modal saham, laba ditahan, dan cadangan. Jika dalam pendanaan perusahaan yang berasal dari modal sendiri masih kurang (deficit) maka perlu dipertimbangkan pendanaan perusahaan yang berasal dari luar, yaitu dari hutang (debt financing).

Dalam memilih alternatif pendanaan tersebut, yang akan menjadi pertimbangan adalah bagaimana perusahaan dapat menciptakan kombinasi yang menguntungkan antara penggunaan sumber dana dari modal sendiri (internal financing) dengan dana yang berasal dari debt (external financing). Dengan kata lain bagaimana perusahaan mampu menciptakan struktur modal seoptimal mungkin. 
Struktur modal yang optimal merupakan keputusan keuangan yang penting karena mempengaruhi kinerja dan nilai perusahaan. Kinerja perusahaan yang bagus berdampak pada harga sahamnya naik di pasar modal, sehingga kemakmuran pemegang saham dapat tercapai. Keputusan struktur modal juga akan sangat menentukan kemampuan perusahaan dalam melakukan aktivitas operasinya dan juga akan berpengaruh terhadap resiko perusahaan itu sendiri. Jika perusahaan meningkatkan leverage maka perusahaan ini dengan sendirinya akan menanggung resiko keuangan yang lebih meningkat.

Ketika manajer menjatuhkan pilihnya dalam pemenuhan modal dengan mengunakan hutang, jelas biaya modal yang timbul sebesar biaya bunga yang dibebankan oleh kreditur. Terlalu banyak hutang juga dapat menghambat perkembangan perusahaan yang pada gilirannya dapat membuat keengganan pemegang saham untuk tetap menanamkan modalnya. (Brigham dan Houston, 2001:4). Sedangkan jika manajer mengunakan modal sendiri maka akan timbul opportunity cost dari dana atau modal sendiri yang digunakan.

Untuk itu sebagian manajer tidak sepenuhnya mendanai perusahaannya dengan modal sendiri (internal financing) tetapi juga disertai penggunaan dana melalui hutang baik itu hutang jangka pendek maupun hutang jangka panjang karena terkait dengan sifat penggunaan dari hutang tersebut yaitu bersifat mengurangi pajak. Dengan demikian ada dua determinan yang digunakan untuk mengidentifikasi struktur modal optimal yaitu weighted average cost of capital (WACC) dan harga saham. Brigham dan Houston (2001:31) mengatakan bahwa struktur modal yang optimum adalah struktur modal yang meminimumkan WACC atau struktur modal yang memaksimumkan harga saham.

Banyak faktor yang mempengaruhi keputusan manajer dalam menentukan struktur modal perusahaan. Faktor-faktor yang dapat mempengaruhi komposisi struktur modal perusahaan diantaranya stabilitas penjualan, struktur aktiva, leverage operasi, tingkat pertumbuhan, profitabilitas, pajak, pengendalian, sikap manajemen, ukuran perusahaan, dan fleksibilitas keuangan (Brigham dan Houston, 2001: 39-41).

Wetson dan Brigham (1994:174-177) berpendapat beberapa faktor yang umumnya dipertimbangkan dalam mengambil keputusan mengenai struktur modal 
pada perusahaan yaitu stabilitas penjualan, struktur aktiva, leverage operasi, tingkat pertumbuhan, profitabilitas, pajak, pengendalian, sikap manajemen, sikap pemberi pinjaman dan perusahaan penilai kredibilitas, kondisi pasar, kondisi internal perusahaan, dan fleksibilitas keuangan. Sedangkan Riyanto (1995:296300) menyebutkan ada tingkat bunga, stabilitas dari "earning", susunan dari aktiva, kadar resiko dari aktiva, besarnya jumlah modal yang dibutuhkan, keadaan pasar modal, sifat manajemen, dan besarnya suatu perusahaan dalam menentukan struktur modal perusahaan.

Penelitian mengenai struktur modal bertujuan untuk menentukan model atau teori struktur modal yang dapat menjelaskan perilaku keputusan pendanaan perusahaan. Dalam menentukan perimbangan antara besarnya hutang dan jumlah modal sendiri yang tercermin pada struktur modal perusahaan, manajer keuangan perlu pula memperhitungkan adanya berbagai faktor yang mempengaruhi struktur modal. Sarjono (1993) menentukan empat faktor yang mempengaruhi struktur modal (D/E) yaitu : Penjualan, Pertumbuhan, Struktur Financial dan Profitabilitas. Beauty (1995) menentukan empat faktor yang mempengaruhi struktur modal (D/E) yaitur Ukuran Perusahaan, Tingkat Operating Leverage, Tingkat Pertumbuhan Penjualan dan Klas Industri. Firdiansjah (1998) menentukan enam faktor yang mempengaruhi struktur keuangan yaitu: Struktur Aktiva, Pertumbuhan Penjualan, Operating Leverage, ROI, Dividend Payout Ratio, dan Ukuran Perusahaan. Sutapa (2006) menentukan lima faktor yang mempengaruhi struktur modal yaitu: Profitabilitas, Pertumbuhan Aktiva, Ukuran Perusahaan, Kepemilikan Asing dan Kepemilikan Pemerintah. Arianto (2008) menentukan empat faktor yang mempengaruhi struktur modal yaitu: Struktur Kepemilikan, Profitablitas, Pertumbuhan Aktiva, dan Ukuran Perusahaan. Sedangkan Cahyadi, dan Fandiawati (2008) menentukan enam faktor yang mempengaruhi struktur modal yaitu: Ukuran Perusahaan (firm size), profitabilitas, Pertumbuhan Perusahaan (growth), Pertumbuhan Penjualan, Asset tangibility, Fleksibility, dan Earning Volatility.

Tujuan yang ingin dicapai peneliti dalam penelitian ini adalah: (1) Menguji hubungan kausalitas antara Struktur aktiva (Structure of activa), Ukuran perusahaan (firm size), Operating leverage, Profitabilitas, Likuiditas, 
Pertumbuhan penjualan (growth of sales) dan struktur modal; (2) Menguji signifikasi Struktur aktiva (Structure of activa) terhadap Operating leverage; (3) Menguji signifikasi Struktur aktiva (Structure of activa) terhadap Pertumbuhan penjualan (growth of sales); (4) Menguji signifikasi antara Operating leverage, dan Pertumbuhan penjualan (growth of sales) terhadap Ukuran perusahaan (firm size); (5) Menguji signifikasi antara Ukuran perusahaan (firm size), terhadap Likuiditas; (6) Menguji signifikasi baik secara parsial maupun simultan antara Struktur aktiva (Structure of activa), dan Pertumbuhan Penjualan (Growth of Sales) terhadap Profitabilitas.

\section{HIPOTESIS PENELITIAN}

Hipotesis yang dikembangkan dalam penelitian ini adalah sebagai berikut : (1) Model diagram jalur yang dikembangkan berdasarkan hubungan kausalitas antara Struktur aktiva/Structure of active (SA), Ukuran perusahaan/firm size (FS), Operating leverage (OL), Profitabilitas (PR), Likuiditas (LQ), Pertumbuhan penjualan/growth of sales (GS) dan struktur modal/Capiltal Structure (CS) adalah sesuai (fit); (2) Struktur aktiva/Structure of activa (SA) berpengaruh terhadap Operating leverage (OL); (3) Struktur aktiva/Structure of active (SA) berpengaruh terhadap Pertumbuhan penjualan/growth of sales (GS); (4) Operating leverage (OL), dan Pertumbuhan penjualan/growth of sales (GS) berpengaruh terhadap Ukuran perusahaan/firm size (FS); (5) Ukuran perusahaan/firm size (FS) berpengaruh terhadap Likuiditas (LQ); (6) Struktur aktiva Structure of active (SA), dan Pertumbuhan penjualan/growth of sales (GS) berpengaruh terhadap Profitabilitas (PR).

\section{METODE}

Hubungan kausalitas antar variabel yang diamati dioperasikan dalam suatu model diagram jalur. Kedudukan masing-masing variabel dalam diagram jalur sebagai berikut :

Tabel 1. Variabel yang Diamati

\begin{tabular}{|c|l|l|c|}
\hline $\begin{array}{c}\text { Model } \\
\text { Teoritis }\end{array}$ & Variabel Endogen & Variabel Exogen & $\begin{array}{c}\text { Variabel } \\
\text { sisa }\end{array}$ \\
\hline 1 & $\begin{array}{c}\text { Struktur Modal / } \\
\text { Capital Structure } \\
\end{array}$ & Likuiditas / Liquidity (LQ) & $\mathrm{e}_{6}$ \\
\cline { 3 - 3 } & $(\mathrm{CS})$ & Ukuran perusahaan/Firm Size (FS) & \\
\cline { 3 - 3 } & & Operating Leverage (OL) & \\
\hline
\end{tabular}




\begin{tabular}{|c|c|c|c|}
\hline $\begin{array}{l}\text { Model } \\
\text { Teoritis }\end{array}$ & Variabel Endogen & Variabel Exogen & $\begin{array}{l}\text { Variabel } \\
\text { sisa }\end{array}$ \\
\hline & & $\begin{array}{l}\text { Struktur aktiva/ structure of active } \\
\text { (SA) }\end{array}$ & \\
\hline & & $\begin{array}{l}\text { Pertumbuhan penjualan / growth of } \\
\text { sales (GS) }\end{array}$ & \\
\hline & & Profitabilitas / Profitability (PR) & \\
\hline 2 & $\begin{array}{l}\text { Operating } \\
\text { Leverage (OL) }\end{array}$ & $\begin{array}{l}\text { Struktur aktiva/ structure of active } \\
\text { (SA) }\end{array}$ & $\overline{e_{1}}$ \\
\hline 3 & $\begin{array}{l}\text { Pertumbuhan } \\
\text { penjualan / growth } \\
\text { of sales }(\mathrm{GS})\end{array}$ & $\begin{array}{l}\text { Struktur aktiva/ structure of active } \\
\text { (SA) }\end{array}$ & $\mathrm{e}_{2}$ \\
\hline \multirow[t]{2}{*}{4} & \multirow{2}{*}{$\begin{array}{l}\text { Ukuran } \\
\text { perusahaan/Firm } \\
\text { Size (FS) }\end{array}$} & Operating Leverage (OL) & \multirow[t]{2}{*}{$\mathrm{e}_{3}$} \\
\hline & & $\begin{array}{l}\text { Pertumbuhan penjualan / growth of } \\
\text { sales }(\mathrm{GS})\end{array}$ & \\
\hline 5 & $\begin{array}{l}\text { Likuiditas } \\
\text { Liquidity (LQ) }\end{array}$ & Ukuran perusahaan/Firm Size (FS) & $\overline{\mathrm{e}_{4}}$ \\
\hline \multirow[t]{2}{*}{6} & \multirow[t]{2}{*}{$\begin{array}{l}\text { Profitabilitas / } \\
\text { Profitability (PR) }\end{array}$} & $\begin{array}{l}\text { Struktur aktiva/ structure of active } \\
\text { (SA) }\end{array}$ & \multirow[t]{2}{*}{$\mathrm{e}_{5}$} \\
\hline & & $\begin{array}{l}\text { Pertumbuhan penjualan / growth of } \\
\text { sales (GS) }\end{array}$ & \\
\hline
\end{tabular}

\section{Teknik Analisa}

Hubungan kausalitas antara variabel yang terdiri dari Struktur Modal dan 6 variabel eksogen/endogen yaitu Struktur aktiva (Structure of activa), Ukuran perusahaan (firm size), Operating leverage, Profitabilitas, Likuiditas, dan Pertumbuhan penjualan (growth of sales) dianalisis dalam suatu diagram jalur. Bilamana data yang diperoleh berdistribusi normal, model Diagram Jalur akan dianalisis dengan Maximum Likelihood $(M L)$ dan bilamana data tidak berdistribusi normal untuk menghasilkan model structural (diagram jalur) data akan diolah dengan menggunakan Bootstrap Maximum Likelihood (Bootstrap ML)

\section{Model Diagram Jalur Teoritis}

Model Diagram Jalur Teoritis yang dikembangkan berdasarkan jastifikasi induktif (empiris) dan teori dalam penelitian ini sebagaimana tersaji pada gambar sebagai berikut :

\section{Gambar 1. Path Diagram Teoritis}




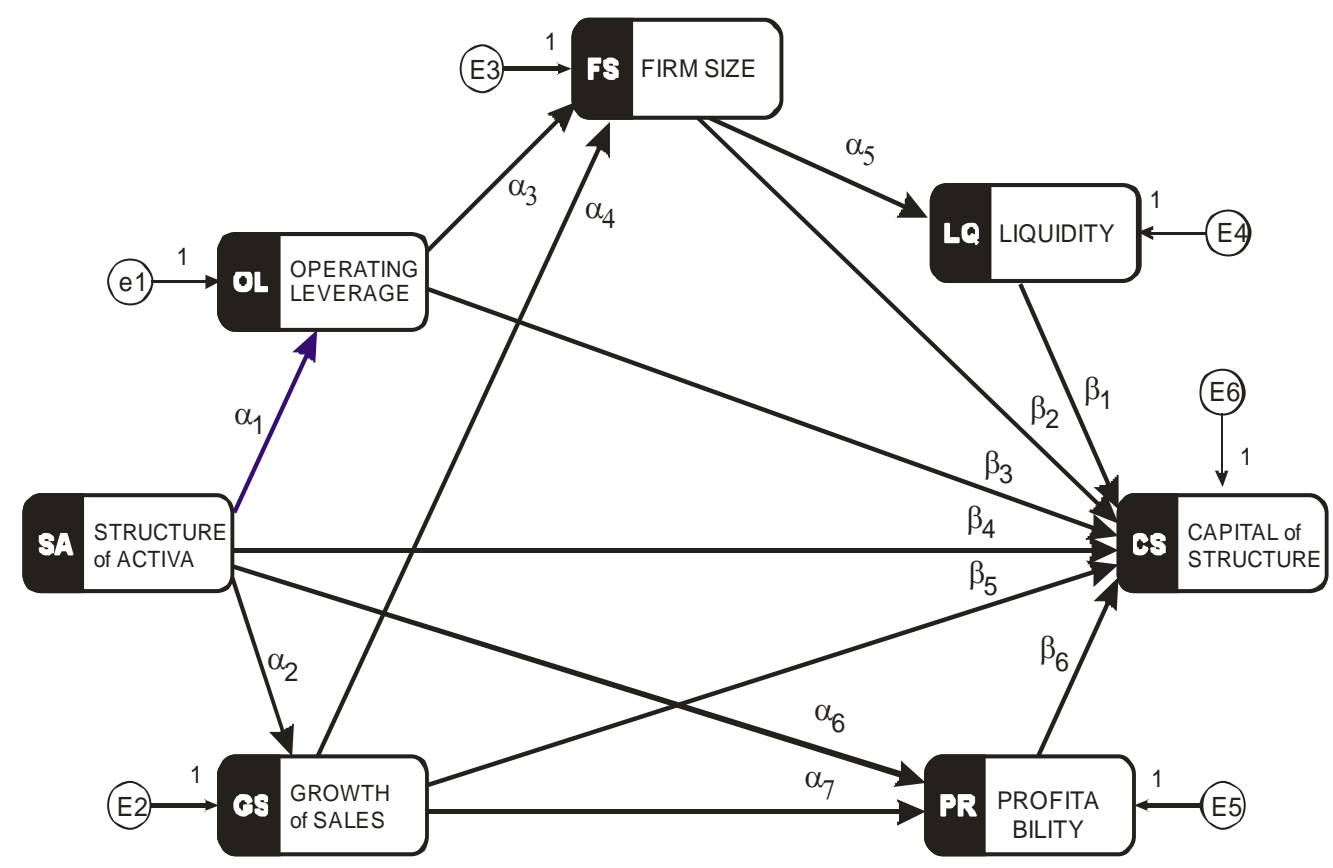

\section{Model Persamaan Struktural}

Enam model persamaan struktural teoritis, yang hasil estimasinya akan digunakan untuk menguji hipotesis 2 sampai hipotesis 6 adalah sebagai berikut :

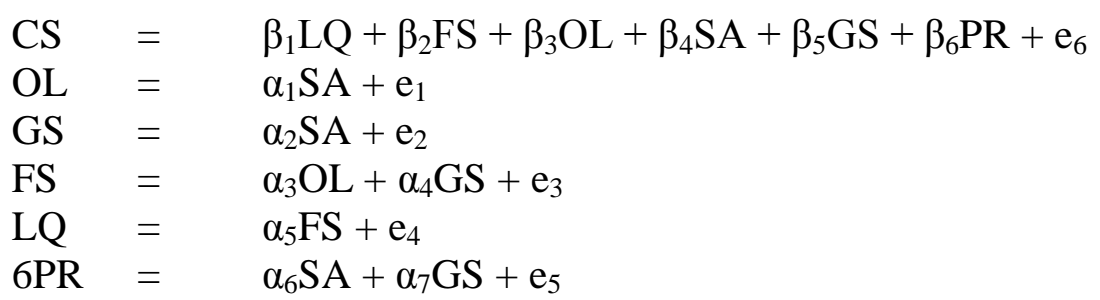

\section{HASIL PENELITIAN}

\section{Pengujian Hipotesis}

Berdasarkan hasil evaluasi normalitas, baik secara univariate maupun multivariate data yang dianalisis tidak berdistribusi normal. Oleh karena itu untuk menghasilkan pemodelan struktur (diagram jalur) yang valid maka teknik analisis yang digunakan Bootstrap Maximum Likelihood (Bootstrap ML) bukan metode Maximum likelihood (ML). Dengan mnggunakan Bootstrap Maximum Likelihood hasil analisis pemodelan struktural sebagai berikut :

\section{Pengujian Model Diagram Jalur Estimasi}

Model hasil estimasi adalah fit (baik), hal ini dapat dilihat dari hasil Goodness of Fit Statistik, yaitu: (1) Chi Square dengan probability 0,068 lebih 
besar dari 0,05 , hal ini mengindikasikan bahwa secara statistik sample covariance matrix tidak jauh berbeda dengan implied covariance matrix; (2) Goodness of Fit (GFI-Statistik) sebesar 0,996 dan Adjusted Goodness of Fit (AGFI)-Statistik sebesar 0,991 masing-masing lebih besar dari Critical Ratio (CR) yaitu 0,90 yang mengindikasikan bahwa model cukup tepat dalam menghasilkan sample covariance matrix, sehingga secara statistik sample covariance matrix tidak jauh berbeda dengan implied covariance matrix; (3) Root Mean Square Error Approximation (RMSEA-statistik) dengan probabilitas 0,068 lebih kecil dari CR-nya yaitu 0,08 mengindikasikan bahwa secara statistik sample covariance matrix tidak berbeda jauh dari population covariance matrix. Kondisi ini mengindikasikan bahwa sampel yang dianalisis mewakili (representative) terhadap populasinya, sehingga hasil analisis ini dapat digeneralisasikan pada populasinya; (4) Hasil pengujian model Bollen-Stein menyatakan bahwa model adalah benar/baik di mana hasil analisis menunjukkan bahwa Bollen-Stein Bootstrap dengan probabilitas $\mathrm{p}=0,085$. Dengan hasil uji ini maka model estimasi yang dihasilkan tidak dapat ditolak dengan kata lain model adalah benar dan bisa diterima. Hal ini konsisten dengan hasil uji beda sample covariance matrix dengan implied covariance matrix di mana $\mathrm{X}^{2}$-statistik dengan probabilitas $0,068>0,05$ yang berarti menerima hipotesis nol yang menyatakan bahwa sample covariance matrix tidak berbeda dengan implied covariance matrix; (5) Seluruh nilai standardized residual covariance kurang dari 2,58. ini menunjukkan bahwa model estimasi yang dihasilkan adalah fit / baik. Tabel berikut ini adalah standardized residual covariance yang dihasilkan dari data yang dianalisis.

Tabel 2: Standardized Residual Covariances

\begin{tabular}{|l|rrrrrrr|}
\hline & SA & OL & GS & FS & PR & LQ & CS \\
\hline SA & 0,000 & & & & & & \\
OL & 0,000 & 0,000 & & & & & \\
GS & 0,000 & 0,000 & 0,000 & & & & \\
FS & $-0,030$ & 0,000 & 0,000 & 0,000 & & & \\
PR & 0,000 & 0,004 & 0,000 & $-0,014$ & 0,000 & & \\
LQ & 0,006 & $-0,037$ & $-0,007$ & 0,020 & $-0,001$ & $-0,001$ & \\
CS & 0,000 & 0,000 & 0,000 & $-0,007$ & 0,000 & 0,003 & 0,000 \\
\hline
\end{tabular}

Sumber data : Hasil Analisis 
Berdasarkan kriteria Goodness of Fit Statistic sebagaimana diuraikan diatas maka hipotesis 1 yang menyatakan "Model diagram jalur yang dikembangkan berdasarkan hubungan kausalitas antara Structure of Active (SA), Firm Size (FS), Operating Leverage (OL), Profitabilitas (PR), Likuiditas (LQ), Growth of Sales (GS) dan Capital Structure (CS) adalah sesuai (fit)" dapat diterima.

\section{Pengujian Persamaan Struktural Estimasi}

Pengujian hipotesis yang menyatakan hubungan kausalitas antara variabel yang ditunjukkan oleh signifikansi parameter (Regression Weights), yang dapat dilihat pada tabel berikut ini :

Tabel 3: Regression Weights

\begin{tabular}{|c|c|c|c|c|c|c|c|}
\hline & & Estimate & $\mathrm{S}, \mathrm{E}$ & $\mathrm{C}, \mathrm{R}$, & $\mathrm{P}$ & Label & $\begin{array}{c}\text { R- } \\
\text { Square }\end{array}$ \\
\hline GS & $\begin{array}{ll}<-- & \text { S } \\
\text { A }\end{array}$ & $-0,101$ & 0,047 & $\overline{-}$ & 0,029 & par_2 & 0,012 \\
\hline $\mathrm{OL}$ & $\begin{array}{ll}<-- & \mathrm{S} \\
\mathrm{A} & \mathrm{A}\end{array}$ & $-0,543$ & 0,222 & 2,452 & 0,014 & par_3 & 0,016 \\
\hline FS & $\begin{array}{ll}<-- & \mathrm{O} \\
& \mathrm{L} \\
<-- & \mathrm{G} \\
& \mathrm{S} \\
\end{array}$ & 0,055 & 0,752 & $\begin{array}{l}0,349 \\
2,451\end{array}$ & $\begin{array}{l}0,727 \\
0,014\end{array}$ & $\begin{array}{l}\text { par_4 } \\
\text { par_7 }\end{array}$ & 0,017 \\
\hline LQ & $<--\quad$ FS & $-0,021$ & 0,007 & 2,873 & 0,004 & par_6 & 0,020 \\
\hline $\begin{array}{l}\text { PR } \\
\text { PR }\end{array}$ & $\begin{array}{ll}<-- & G \\
& S \\
<-- & S \\
& A\end{array}$ & $-0,118$ & $\begin{array}{l}0,025 \\
0,022\end{array}$ & $\begin{array}{c}1,946 \\
- \\
5,286\end{array}$ & $\begin{array}{l}0,052 \\
* * *\end{array}$ & $\begin{array}{c}\text { par_1 }_{-1} \\
1 \\
\operatorname{par}_{-} 1 \\
2\end{array}$ & 0,078 \\
\hline $\mathrm{CS}$ & $<-\begin{array}{l}\text { S } \\
\text { A }\end{array}$ & 0,325 & 0,035 & 9,240 & $* * *$ & par_1 & \multirow{6}{*}{0,259} \\
\hline $\mathrm{CS}$ & $<--\quad \begin{array}{l}G \\
S\end{array}$ & 0,026 & 0,038 & 0,677 & 0,499 & par_5 & \\
\hline CS & $\begin{array}{ll}<--- & \mathrm{O} \\
& \mathrm{L}\end{array}$ & $-0,010$ & 0,008 & $\begin{array}{c}- \\
1,248\end{array}$ & 0,212 & par_8 & \\
\hline $\mathrm{CS}$ & $<---\quad F S$ & 0,000 & 0,003 & $\begin{array}{c}- \\
0,082\end{array}$ & 0,935 & par_9 & \\
\hline CS & $\begin{array}{ll}<-- & \text { L } \\
\text { L } & \text { Q }\end{array}$ & $-0,037$ & 0,018 & 2,027 & 0,043 & par_1 & \\
\hline CS & $<---\quad P R$ & $-0,273$ & 0,078 & $\begin{array}{c}- \\
3,521\end{array}$ & $* * *$ & par_1 & \\
\hline
\end{tabular}

Sumber data : Hasil Analisis 
Tabel diatas mengindikasikan bahwa interdependensi antar variabel yang dianalisis secara statistik ada yang nyata pada $\mathrm{p}=0,05$, nyata pada $\mathrm{p}=0,10$ dan sangat nyata pada $p=0,01$. Hubungan kausalitas yang tidak bermakna yaitu hubungan antara FS-OL, CS-FS, CS-GS dan CS-OL.

Untuk mempermudah pembahasan regression weights diberikan tanda bintang sebagai berikut :

Regression weight dengan 3 bintang $\quad$ : sangat nyata pada $\mathrm{p}=0,001$

Regression weight dengan 2 bintang $\quad$ : nyata pada $\mathrm{p}=0,005$

Regression weight dengan 1 bintang $\quad$ : tidak nyata pada $p>0,05$

Tabel 4. Pengujian Persamaan Struktural 1

\begin{tabular}{|l|l|l|l|l|l|l|l|}
\hline $\mathrm{CS}$ & $=\begin{array}{l}0,325 * * * \\
\mathrm{SA}+\end{array}$ & $0,026 * \mathrm{GS}-$ & $0,01 *$ OL - & $0.0 *$ FS - & $0,037 * *$ LQ - & $\begin{array}{l}0,273 \\
* * *\end{array}$ \\
\hline $\mathrm{t}$-stat & $=$ & 9,240 & 0,677 & $-1,248$ & $-0,082$ & $-2,027$ & $-3,521$ \\
\hline $\mathrm{P}$ & $=$ & $* * *$ & 0,499 & 0,212 & 0,935 & 0,043 & $* * *$ \\
\hline $\mathrm{R}_{\text {-square }}=0,259$
\end{tabular}

Model persamaan struktural estimasi di atas menunjukkan bahwa koefisien regresi Structure of Activa (SA) sebesar 0,325 dan koefisien regresinya ini secara statistik sangat nyata. Koefisien regresi Growth of Sales (GS) sebesar 0,026 dan koefisien regresinya ini secara statistik tidak nyata. Koefisien regresi Operating Leverage (OL) sebesar negatif 0,01 dan koefisien regresinya ini secara statistik tidak nyata. Koefisien regresi Firm Size (FS) sebesar 0.00 dan koefisien regresinya ini secara statistik tidak nyata. Koefisien regresi Liquidity (LQ) sebesar negatif 0,037 dan koefisien regresinya ini secara statistik nyata. Koefisien regresi Profitability (PR) sebesar negatif 0,273 dan koefisien regresinya ini secara statistik sangat nyata.

Multiple R-Square sebesar 0,259 mengindikasikan bahwa perubahan Capital Structure dijelaskan secara bersama-sama oleh perubahan Structure of Activa (SA), Growth of Sales (GS), Operating Leverage (OL), Firm Size (FS), Liquidity (LQ) dan Profitability (PR) sebesar 25,9\% sedangkan sisanya 74,1\% dijelaskan oleh perubahan variabel lain yang tidak masuk dalam model.

\section{Pengujian Persamaan Struktural 2}

$\mathrm{OL} \quad=-0,543 * * \mathrm{SA}$

$\mathrm{t}$-stat $=-2,452$

$\mathrm{P} \quad=0,014$

R-square $=0,016$ 
Model persamaan struktural estimasi di atas menunjukkan bahwa koefisien regresi Structure of Activa (SA) sebesar negative 0,543 dan koefisien regresinya ini secara statistik nyata. Hasil analisis tersebut mengindikasikan bahwa Structure of Activa (SA) berpengaruh terhadap Operating Leverage (OL). Multiple RSquare sebesar 0,016 mengindikasikan bahwa perubahan Operating Leverage (OL) dijelaskan oleh perubahan Structure of Activa (SA) sebesar 1,6\% sedangkan sisanya $98,4 \%$ dijelaskan oleh perubahan variabel lain yang tidak masuk dalam model.

\section{Pengujian Persamaan Struktural 3}

$\mathrm{GS}=-0,101 *$ SA

$\mathrm{t}$-stat $=-2,177$

$\mathrm{P} \quad=0,029$

R-square $=0,012$

Model persamaan struktural estimasi di atas menunjukkan bahwa koefisien regresi Structure of Activa (SA) sebesar negative 0,101 dan koefisien regresinya ini secara statistik nyata. Hasil analisis tersebut mengindikasikan bahwa Structure of Activa (SA) berpengaruh terhadap Growth of Sales (GS). Multiple R-Square sebesar 0,012 mengindikasikan bahwa perubahan Growth of Sales (GS) dijelaskan oleh perubahan Structure of Activa (SA) sebesar 1,2\% sedangkan sisanya 98,8\% dijelaskan oleh perubahan variabel lain yang tidak masuk dalam model.

\begin{tabular}{llll}
\multicolumn{3}{l}{ Pengujian Persamaan Struktural 4 } \\
FS & $=0,055^{*} \mathrm{OL}$ & $+1,843^{*} * \mathrm{GS}$ \\
$\mathrm{t}-\mathrm{stat}$ & $=$ & 0,349 & 2,451 \\
$\mathrm{P}$ & $=$ & 0,727 & 0,014 \\
$\mathrm{R}-\mathrm{square}$ & $=$ & 0,017 &
\end{tabular}

Model persamaan struktural estimasi di atas menunjukkan bahwa koefisien regresi Operating Leverage (OL) sebesar 0,055 dan koefisien regresinya ini secara statistik tidak nyata. Koefisien regresi Growth of Sales (GS) sebesar 1,843 dan koefisien regresinya ini secara statistik tidak nyata. Multiple R-Square sebesar 0,017 mengindikasikan bahwa perubahan struktur modal dijelaskan secara bersama-sama oleh perubahan Operating Leverage (OL), dan Growth of Sales (GS) sebesar 1,7\% sedangkan sisanya 98,3\% dijelaskan oleh perubahan variabel lain yang tidak masuk dalam model. 


\section{Pengujian Persamaan Struktural 5}

$\begin{array}{lll}\mathrm{LQ} & =-0,021 * * \mathrm{FS} \\ \mathrm{t} \text {-stat } & =-2,873 \\ \mathrm{P} & =0,004 \\ \mathrm{R} \text {-square } & =0,020\end{array}$

Model persamaan struktural estimasi di atas menunjukkan bahwa koefisien regresi Firm Size (FS) sebesar negative 0,021 dan koefisien regresinya ini secara statistik nyata. Hasil analisis tersebut mengindikasikan bahwa Firm Size (FS) berpengaruh terhadap Liqudity (LQ). Multiple R-Square sebesar 0,016 mengindikasikan bahwa perubahan Liqudity (LQ) dijelaskan oleh perubahan Firm Size (FS) sebesar 2,1\% sedangkan sisanya 97,9\% dijelaskan oleh perubahan variabel lain yang tidak masuk dalam model.

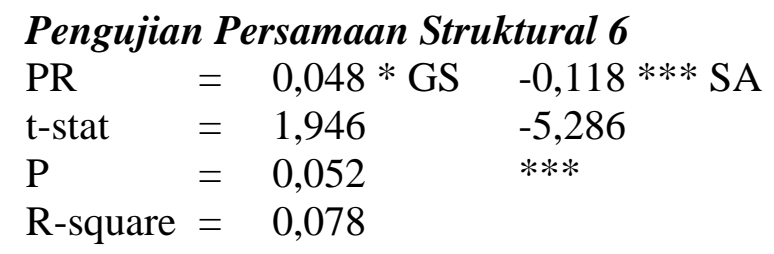

Model persamaan struktural estimasi di atas menunjukkan bahwa koefisien regresi Growth of Sales (GS) sebesar 0,048 dan koefisien regresinya ini secara statistik tidak nyata. Koefisien regresi Structure of Activa (SA) sebesar negatif 0,118 dan koefisien regresinya ini secara statistik sangat nyata. Multiple RSquare sebesar 0,017 mengindikasikan bahwa perubahan Capital Structure dijelaskan secara bersama-sama oleh perubahan Growth of Sales (GS) dan Structure of Activa (SA) sebesar 7,8\% sedangkan sisanya 92,2\% dijelaskan oleh perubahan variabel lain yang tidak masuk dalam model.

\section{PENGARUH ANTAR VARIABEL}

Standardized effect disajikan dengan maksud agar pengaruh antar variabel yang satu dengan pengaruh antara variabel lainnya dapat diperbandingkan. Tabel 5 berikut ini adalah pengaruh langsung terstandar (standardized direct effects), pengaruh tidak langsung terstandar (standardized indirect effect) dan pengaruh total terstandar (standardized total effects). 
Tabel 5: Standardized Direct Effects (SDE), Standardized Indirect Effects dan Standardized Total Effects (STE)

\begin{tabular}{|c|c|c|c|c|c|c|}
\hline \multicolumn{2}{|c|}{$\begin{array}{c}\text { Hubungan Antar } \\
\text { Variabel }\end{array}$} & $\begin{array}{c}\text { Jalur yang } \\
\text { dilalui }\end{array}$ & SDE & SIE & STE \\
\hline SA & $--->$ & OL & - & -0.125 & 0.000 & -0.125 \\
\hline SA & $--->$ & GS & - & -0.111 & 0.000 & -0.111 \\
\hline SA & $--->$ & FS & GS & 0.000 & -0.016 & -0.016 \\
\hline SA & $--->$ & PR & GS & -0.253 & -0.010 & -0.264 \\
\hline SA & $--->$ & LQ & GS, FS & 0.000 & 0.002 & 0.002 \\
\hline SA & $--->$ & CS & GS, PR, FS, LQ & 0.430 & 0.048 & 0.478 \\
\hline OL & $--->$ & FS & - & 0.018 & 0.000 & 0.018 \\
\hline OL & $--->$ & LQ & - & 0.000 & -0.003 & -0.003 \\
\hline OL & $--->$ & CS & - & -0.057 & 0.000 & -0.057 \\
\hline GS & $--->$ & FS & - & 0.127 & 0.000 & 0.127 \\
\hline GS & $--->$ & PR & - & 0.093 & 0.000 & 0.093 \\
\hline GS & $--->$ & LQ & FS & 0.000 & -0.018 & -0.018 \\
\hline GS & $--->$ & CS & FS, LQ, PR & 0.031 & -0.015 & 0.017 \\
\hline FS & $--->$ & LQ & - & -0.141 & 0.000 & -0.141 \\
\hline FS & $--->$ & CS & LQ & -0.004 & 0.013 & 0.010 \\
\hline PR & $--->$ & CS & - & -0.169 & 0.000 & -0.169 \\
\hline LQ & $--->$ & CS & - & -0.095 & 0.000 & -0.095 \\
\hline Sumber
\end{tabular}

Sumber data : Hasil Analisis

\section{Standardized Direct Effects (SDE)}

Pengaruh langsung Structure of Activa (SA) terhadap Operating Leverage (OP) sebesar negatif 0,125. Hal ini menunjukkan bahwa jika Structure of Activa (SA) naik sebesar 1\% maka Operating Leverage (OP) akan turun sebesar 0,125\%. Sebaliknya jika Structure of Activa (SA) turun sebesar 1\% maka Operating Leverage (OP) akan naik sebesar 0,125\%. Disamping itu Structure of Activa (SA) juga berpengaruh langsung terhadap Growth of Sales (GS), Profitability (PR), dan Capital Structure (CS); dimana masing-masing sebesar negatif 0,111 pengaruhnya terhadap Growth of Sales (GS), negatif 0,253 pengaruhnya terhadap Profitability (PR), dan 0,430 pengaruhnya terhadap Capital Structure (CS). Operating Leverage (OL) berpengaruh langsung terhadap Firm Size (FS) dan Capital Structure (CS), masing masing sebesar 0,018 pengaruhnya terhadap Firm Size (FS) dan negatif 0,057 pengaruhnya terhadap Capital Structure (CS).

Beberapa variabel yang dipengaruh oleh Growth of Sales (GS) daiantaranya Firm Size (FS), Profitabilty (PR) dan Capital Structure (CS). 
Besarnya pengaruh Growth of Sales (GS) terhadap Firm Size (FS) sebesar 0,127, terhadap Profitabilty (PR) sebesar 0,093 dan terhadap Capital Structure (CS). Sebesar 0,031. Firm Size (FS) mempunyai pengaruh langsung terhadap Liquidity (LQ) dan Capital Structure (CS) sebesar negatif 0,141 terhadap Liquidity (LQ) dan negatif 0,004 terhadap Capital Structure (CS). Setiap perubahan Profitability (PR) sebesar 1\% akan mempunyai pengaruh langsung terhadap Capital Strucutre (CS) sebesar 0,169\% secara berbanding terbalik. Demikian pula Setiap perubahan Liquidity (LQ) sebesar 1\% akan mempunyai pengaruh langsung terhadap Capital Strucutre (CS) sebesar 0,095\% secara berbanding terbalik.

\section{Standardized Indirect Effects (SIE)}

Standardized Indirect Effects antara variabel yang diamati merupakan pengaruh variabel satu terhadap variabel lain melalui variabel antara. Structure of Activa (SA) berpengaruh tidak langsung terhadap Firm Size (FS) sebesar negatif 0,016. Hal ini mengindikasikan bahwa Firm Size (FS) akan naik sebesar 0,016\% sebagai dampak dari turunnya Structure of Activa (SA) sebesar 1\%. Disamping itu Structure of Activa (SA) juga memiliki pengaruh tidak langsung terhadap Profitability (PR), Liquidity (LQ) dan Capital Structure (CS). Besarnya pengaruh tak langsung Structure of Activa (SA) terhadap masing-masing variabel sebagai berikut : negatif 0,01 pengaruh tidak langsung terhadap Profitability (PR), 0,002 pengaruh tidak langsung terhadap Liquidity (LQ) dan 0,048 pengaruh tidak langsung terhadap Capital Structure (CS).

Operating Leverage (OL) berpengaruh tidak langsung terhadap Liquidity (LQ) sebesar negatif 0,003. Hal ini mengindikasikan bahwa Liquidity (LQ) akan naik sebesar $0,003 \%$ sebagai dampak dari turunnya Operating Leverage (OL) sebesar 1\%. Disamping itu Liquidity (LQ) juga dipengaruhi secara tidak langsung oleh Growth of Sales (GS) sebesar negatif 0,018.

Capital Structure (CS) dipengaruhi secara tak langsung oleh Growth of Sales dan Firm Size (FS) masing-masing sebesar negatif 0,015 dan 0,013. Growth of Sales (GS) memiliki koefisien pengaruh negatif, artinya setiap kenaikan Growth of Sales (GS) sebesar 1\% akan direspon oleh penurunan Capital Structure (CS) sebesarnya $0,015 \%$. Sebaliknya setiap penurunan Growth of Sales (GS) 
sebesar $1 \%$ akan direspon oleh kenaikan Capital Structure (CS) sebesarnya 0,015\%. Sedangkan Firm Size (FS) memiliki koefisien pengaruh tak langsung terhadap Capital Structure (CS) positif. Artinya setiap perubahan Firm Size (FS) sebesar 1\% akan direspon tak langsung oleh Capital Structure (CS) sebesar $0,013 \%$.

\section{Standardized Total Effects (STE)}

Standardized Total Effects merupakan totalitas dari Standardized Direct Effects dengan Standardized Indirect Effects. Berdasarkan tabel diatas menunjukkan bahwa variabel yang pengaruhnya terbesar adalah: Structure of Activa (SA) terhadap Capital Structure (CS) sebesar 0,478.

\section{PEMBAHASAN}

\section{Hipotesis I:}

\section{Struktur aktiva (tangibility of assets) terhadap struktur modal}

Nilai koefisien regresi Structure of Activa (SA) sebesar 0,325 dan koefisien regresinya ini secara statistik sangat nyata. Hasil analisis tersebut menunjukkan bahwa setiap kenaikan struktur aktiva sebesar 1 satuan akan berakibat pada kenaikan struktur modal sebesar 0,325 satuan. Dampak logis tersebut tercermin pada setiap terjadi pengadaan aktiva tetap (fixed asset) perusahaan akan berupaya untuk memenuhi kebutuhan pendanaannya dari berbagai macam sumber pendanaan (modal sendiri atau modal asing).

Nilai Standardized Direct Effects sebesar 0,430 menunjukkan pengaruh langsung Structure of Activa (SA) terhadap struktur modal. Hasil penelitian ini mendukung hasil penelitian Firdiansjah (1998) dan Arianto (2008) menunjukkan hal yang serupa yakni struktur aktiva mempunyai pengaruh positif dan signifikan terhadap struktur modal.

\section{Ukuran perusahaan (size) terhadap struktur modal}

Koefisien regresi Firm Size (FS) sebesar 0.00 dan koefisien regresinya ini secara statistik tidak nyata serta nilai Standardized Direct Effects sebesar -0.004, hal tersebut mengidentifikasikan Ukuran perusahaan (size) tidak berpengaruh terhadap struktur modal. 
Secara teoritis Perusahaan yang ukurannya relatif besar, kecenderungan penggunaan dana eksternal juga semakin besar. Hal ini disebabkan kebutuhan dana juga semakin meningkat seiring dengan pertumbuhan perusahaan. Dalam hal ini perusahaan besar mungkin dapat memperoleh keuntungan dalam skala ekonomi dengan melakukan emisi hutang jangka panjang, dan mungkin juga memiliki kekuatan bargaining terhadap kreditur. Namun hasil analisis menunjukkan lain, bahwa firm size tidak berpengaruh terhadap struktur modal. Hal tersebut terjadi karena banyaknya faktor yang harus dipertimbangkan oleh perusahaan (perusahan besar, perusahan sedang, ataupun perusahan kecil) dalam penentuan struktur modal. Hasil penelitian ini bertentangan dengan penelitian Firdiansjah (1998) dan Sutapa (2006) dan mendukung penelitian Sarjono (1993), Beauty (1995), dan Arianto (2008) menunjukkan bahwa firm size tidak berpengaruh terhadap struktur modal.

\section{Operating leverage terhadap struktur modal}

Koefisien regresi Operating Leverage (OL) sebesar negatif 0,01 dan koefisien regresinya ini secara statistik tidak nyata. Hal tersebut menunjukkan bahwa Operating Leverage tidak berpengaruh terhadap struktur modal. Secara teoritis Operating leverage timbul pada saat perusahaan menggunakan aktiva yang memiliki biaya-biaya operasi tetap. Leverage operasi mencerminkan pengaruh besarnya biaya tetap terhadap laba perusahaan. Dalam hal ini perubahan biaya tetap yang kecil akan mengakibatkan perubahan laba yang besar. Dengan penggunaan biaya tetap yang rendah akan menghasilkan laba yang besar. Laba yang besar ini memungkinkan perusahaan untuk membiayai sebagian besar kebutuhan pendanaan dengan dana yang dihasilkan secara internal. Semakin tinggi laba yang diperoleh, berarti semakin rendah kebutuhan dana eksternal (hutang), sehingga semakin rendah pula struktur modalnya.

Namun hasil analisis menunjukkan lain, bahwa operating leverage tidak berpengaruh terhadap struktur modal. Hal tersebut terjadi karena banyaknya faktor yang harus dipertimbangkan oleh perusahaan dalam penentuan struktur modal. Hasil penelitian tersebut mendukung penelitian Beauty (1995), dan 
Firdiansjah (1998) bahwa Operating Leverage tidak berpengaruh terhadap struktur modal.

\section{Profitabilitas terhadap struktur modal}

Koefisien regresi Profitability (PR) sebesar negatif 0,273 dan koefisien regresinya ini secara statistik sangat nyata. Hasil analisis ini menunjukkan bahwa setiap terdapat kenaikan profitabilitas sebesar 1 satuan akan berdampak pada penurunan struktur modal sebesar 0,273 satuan. Hal tersebut mengindikasikan bahwa perusahaan yang profitable cenderung untuk memiliki hutang yang lebih kecil. Semakin tinggi keuntungan yang diperoleh, berarti semakin rendah kebutuhan dana eksternal (hutang), sehingga semakin rendah pula struktur modalnya. Nilai Standardized Direct Effects sebesar -0.169 menunjukkan pengaruh langsung Profitabilitas terhadap struktur modal. Hasil penelitian ini mendukung penelitian Sarjono (1993), Firdiansjah (1998), dan Sutapa (2006) menunjukkan hal yang serupa yakni Profitabilitas mempunyai pengaruh negatif dan signifikan terhadap struktur modal.

\section{Likuiditas terhadap struktur modal}

Koefisien regresi Liquidity (LQ) sebesar negatif 0,037 dan koefisien regresinya ini secara statistik nyata. Hasil penelitian tersebut menunjukkan bahwa setiap kenaikan liquiditas sebesar 1 satuan akan berdampak pada penurunan struktur modal sebesar 0,037 satuan. Semakin besar likuiditas (asset) perusahaan maka struktur modalnya (dalam hal ini hutang) akan semakin berkurang, karena perusahaan yang mempunyai total aktiva yang besar kemampuan untuk membayar hutangnya pun lebih besar. Nilai Standardized Direct Effects sebesar -0.095 menunjukkan bahwa Likuiditas berpengaruh negatif terhadap struktur modal. Hasil penelitian Sutapa (2006) menunjukkan hal yang serupa yakni Likuiditas mempunyai pengaruh negatif dan signifikan terhadap struktur modal.

\section{Pertumbuhan penjualan (growth of sales) terhadap struktur modal}

Koefisien regresi Growth of Sales (GS) sebesar 0,026 dan koefisien regresinya ini secara statistik tidak nyata serta nilai Standardized Direct Effects 
sebesar 0.031 menunjukkan bahwa Pertumbuhan penjualan (growth of sales) tidak berpengaruh terhadap struktur modal.

Secara umum semakin stabil tingkat penjualan yang berarti keuntungannya pun semakin stabil, maka besar kemungkinan perusahaan mampu memenuhi kewajiban tetapnya. Dengan demikian perusahaan bisa membelanjai kegiatannya dengan proporsi hutang yang lebih besar. Namun hasil penelitian menunjukkan lain, ternyata pertumbuhan penjualan tidak berpengaruh terhadap struktur modal.

Hasil penelitian ini mendukung hasil penelitian Sarjono (1993) dan Beauty (1995) dan Firdiansjah (1998) menunjukkan bahwa pertumbuhan penjualan tidak pengaruh terhadap struktur modal.

\section{Hipotesis II}

Koefisien regresi Structure of Activa (SA) sebesar negative 0,543 dan koefisien regresinya ini secara statistik nyata serta nilai Standardized Direct Effects sebesar -0.125. Nilai Koefisien regresi tersebut menunjukkan bahwa setiap kenaikan sebesar 1 satuan Structure of Activa (SA) akan menurunkan operating leverage sebesar 0,543 . Hal tersebut terjadi karena dengan pengadaan aktiva tetap perusahaan akan menanggung biaya tetap yang muncul sebagai akibat dari aktiva tetap tersebut.

\section{Hipotesis III}

Koefisien regresi Structure of Activa (SA) sebesar negative 0,101 dan koefisien regresinya ini secara statistik sangat nyata serta nilai Standardized Direct Effects sebesar -0.111 menunjukkan bahwa Struktur Aktiva (Structure of Activa) berpengaruh negatif terhadap Growth of Sales. Hasil penelitian ini menunjukkan bahwa setiap peningkatan struktur aktiva satu satuan akan berdampak pada penurunan Growth of Sales sebesar 0,101 satuan.

Bagi perusahaan manufaktur pengadaan aktiva yang bersifat tetap adalah sebuah keharusan, agar perusahaan mampu berproduksi. Harapan pengadaan aktiva tetap tersebut akan memberikan efek pada pengingkatan tingkat pertumbuhan penjualan. Namun ternyata dengan pengadaan aktiva tetap tersebut perusahaan belum mampu meningkatkan pertumbuhan penjualannya. Akibatnya dengan pengadaan aktiva tersebut justru berpengaruh negatif terhadap pertumbuhan penjualan. 


\section{Hipotesis IV}

\section{Operating Leverage terhadap Firm Size}

Koefisien regresi Operating Leverage (OL) sebesar 0,055 dan koefisien regresinya ini secara statistik tidak nyata serta nilai Standardized Direct Effects sebesar 0.018 menunjukkan bahwa penggunaan leverage dalam pembiayaan investasi tidak mempengaruhi Firm Size perusahaan.

Secara teoritis penggunaan leverage dalam pembiayaan investasi akan meningkatkan kinerja dan nilai perusahaan. Kinerja perusahaan yang bagus berdampak pada harga sahamnya naik di pasar modal, sehingga firm size akan juga meningkat. Disisi lain meningkatnya leverage resiko keuangan yang harus ditanggung oleh perusahaan juga meningkat. Dengan demikian pemakaian leverage bisa berpengaruh positif dan atau negatif terhadap .

Namun hasil penelitian menunjukankan lain, dimana penggunaan leverage dalam pembiayaan investasi tidak mempengaruhi Firm Size perusahaan. Hal tersebut disebabkan banyak faktor lain yang mempengaruhi firm size.

\section{Growth of Sales terhadap Firm Size}

Koefisien regresi Growth of Sales (GS) sebesar 1,843 dan koefisien regresinya ini secara statistik tidak nyata serta nilai Standardized Direct Effects sebesar 0.127 menunjukkan bahwa Pertumbuhan penjualan tidak mempengaruhi nilai Firm Size perusahaan.

Secara teoritis dengan stabilnya penjualan apalagi dengan pertumbuhan penjualan yang semakin meningkat akan mendorong firm size. Dengan kata lain Pertumbuhan penjualan yang stabil akan mendorong pencapaian laba perusahaan selanjutnya akan meningkatkan nilai Firm Size semakin tinggi. Namun hasil penelitian ini tidak demikian adanya, ternyata pertumbuhan penjualan tidak berpengaruh terhadap ukuran perusahaan. Hal tersebut dimungkinkan pertumbuhan penjualan belum mampu meningkatkan nilai dari total aktiva dan atau nilai pasar saham, sebagai indikator lain dari firm size.

\section{Hipotesis V}

Koefisien regresi Firm Size (FS) sebesar negative 0,021 dan koefisien regresinya ini secara statistik nyata serta nilai Standardized Direct Effects sebesar 
-0.141 menunjukkan bahwa meningkatnya ukuran perusahaan sebesar 1 satuan menurunkan tingkat likuiditas sebesar 0,021 satuan.

Meningkatnya nilai firm size ternyata justru menurunkan tingkat likuiditas perusahaan, demikian sebaliknya. Hal tersebut mungkin disebabkan karena perusahaan dalam membiayai operasionalnya banyak menggunakan leverage, sehingga meningkatnya firm size juga meningkatkan beban perusahaan dalam membiayai beban tetapnya.

\section{Hipotesis VI}

\section{Structure Aktiva terhadap Profitability}

Koefisien regresi Structure of Activa (SA) sebesar negatif 0,118 dan koefisien regresinya ini secara statistik sangat nyata serta nilai Standardized Direct Effects sebesar -0.253 menunjukkan bahwa penggunaan sumber dana untuk pengadaan aktiva bersifat tetap berdampak pada tingkat profitabilitas.

Ternyata dengan penggunaan sumber dana untuk pengadaan aktiva tetap pada akhirnya perusahaan akan menanggung beban yang bersifat tetap, akan menurunkan nilai profitabilitas perusahaan.

\section{Growth of Sales terhadap Profitability}

Koefisien regresi Growth of Sales (GS) sebesar 0,048 dan koefisien regresinya ini secara statistik tidak nyata serta nilai Standardized Direct Effects sebesar 0.093 menunjukkan bahwa pertumbuhan penjualan yang stabil akan mendorong pencapaian laba perusahaan namun belum mampu meningkatkan nilai profitability perusahaan. Hal tersebut menunjukkan nampak pada rata-rata tingkat profitabilitas perusahaan sampel yang relatif sangat kecil yaitu sebesar 0,0512194.

\section{KESIMPULAN DAN SARAN}

\section{Kesimpulan}

Berdasarkan hasil pengujian hipotesis yang dilakukan terhadap 510 sampel perusahaan industri manufaktur dan pembahasan pada bab sebelumnya, diperoleh kesimpulan: (1) Model struktural estimasi yang dihasilkan dalam bentuk Path Diagram yang mencerminkan hubungan kausalitas antara Struktur aktiva/Structure of active (SA), Ukuran perusahaan/firm size (FS), Operating leverage (OL), Profitabilitas (PR), Likuiditas (LQ), Pertumbuhan 
penjualan/growth of sales (GS) dan struktur modal/Capiltal Structure (CS) adalah sesuai (fit); (2) Dari Hasil Uji Persamaan Struktural hipotesis II, III, dan V dapat dibuktikan (diterima) sedangkan hipotesis IV dan V tidak dapat dibuktikan (diterima).

\section{Saran}

Adapun saran yang dapat diberikan adalah sampel penelitian lebih baik jika diambil dari sub-sektor perusahaan manufaktur di Indonesia sehingga memberikan gambaran yang lebih spesisfik dan mendalam dalam pengambilan keputusan struktur modal sub sektor perusahaan manufaktur tersebut. Disamping itu perlu untuk memperpanjang periode penelitian guna lebih baik akan meningkatkan keakuratan data penelitian sehingga diperoleh estimasi yang lebih represntatif.

\section{DAFTAR RUJUKAN}

Arianto, Tulus. 2008. Struktur kepemilikan, profitablitas, pertumbuhan aktiva, dan ukuran perusahaan terhadap struktur modal pada perusahaan manufaktur Jurnal Keuangan dan Perbankan, Vol 12, No. 1. Program Studi Keuangan dan Perbankan, Universitas Merdeka Malang..

Beauty. 1995. Analisis Faktor yang mempengaruhi Struktur Financial pada beberapa jenis industri di Kodya Ujung Pandang. Tesis. Program Pascasarjana, Universitas Gadjah Mada, Yogyakarta. Tidak dipublikasikan

Brigham, Euguene, F. dan Houston, Joel F. 2001. Manajemen Keuanga. Buku II. Edisi ke Delapan. Jakarta: Erlangga.

Cahyadi, Fandy dan Fandiawati. Melly. 2008. Analisa Faktor-Faktor Yang Mempengaruhi Struktur Modal Pada Perusahaan Manufaktur Yang Terdaftar di Bursa Efek Jakarta Tahun 2002-2005. Skripsi. Universitas Kristen Petra Surabaya. Tidak dipublikasikan.

Firdiansjah. 1998. Analisis Beberapa Variabel yang mempengaruhi struktur modal pada perusahaan-perusahaan Properti yang Go Public dan Listing di BEJ. Tesis. Program Pascasarjana. Universitas Brawijaya Malang. Tidak dipublikasikan

Riyanto. Bambang. 1995. Dasar-dasar Pembelanjaan Perusahaan. Edisi keempat. Cetakan ketuju. Yogyakarta: Yayasan Badan Penerbit Gadjah Mada.

Sarjono.1993. Telaah Optimal Struktur Modal Guna memaksimumkan RMS serta Faktor-Faktor yang mempengaruhinya. Tesis. Program Pascasarjana. Universitas Indonesia. Jakarta. Tidak dipublikasikan 
Sutapa. 2006. Analisis faktor penentu struktur modal: Studi Empiris pada Emiten Syariah di BEJ. Tesis. Program Pascasarjana. Universitas Brawijaya Malang. Tidak dipublikasikan

Weston. J. Fred dan Brigham. Eugene F.. 1994. Dasar-Dasar Manajemen Keuangan. Alih Bahasa Alfonsus Sirait. SE. Jilid 2. Edisi Kesembilan. Jakarta: Penerbit Erlangga.

Weston. J. Fred dan Copeland. Thomas E.. 1997. Manajemen Keuangan. Alih Bahasa Jaka wasana dan Kibrandoko. Jilid 2. Edisi kesembilan. Jakarta: Binarupa Aksara. 